$2-2-2018$

\title{
Development of optimized conditions for Glaser-Hay bioconjugations
}

Zachary M. Nimmo

John F. Halonski

Lindsay E. Chatkewitz

Douglas D. Young dyoung01@wm.edu

Follow this and additional works at: https://scholarworks.wm.edu/aspubs

\section{Recommended Citation}

Nimmo, Z. M., Halonski, J. F., Chatkewitz, L. E., \& Young, D. D. (2018). Development of optimized conditions for Glaser-Hay bioconjugations. Bioorganic chemistry, 76, 326-331.

This Article is brought to you for free and open access by the Arts and Sciences at W\&M ScholarWorks. It has been accepted for inclusion in Arts \& Sciences Articles by an authorized administrator of W\&M ScholarWorks. For more information, please contact scholarworks@wm.edu. 


\title{
Short communication
}

\section{Development of optimized conditions for Glaser-Hay bioconjugations}

\author{
Zachary M. Nimmo, John F. Halonski, Lindsay E. Chatkewitz, Douglas D. Young* \\ Department of Chemistry, The College of William \& Mary, Williamsburg, VA 23187, USA
}

\section{A R T I C L E I N F O}

\section{Article history:}

Received 24 October 2017

Revised 27 November 2017

Accepted 29 November 2017

Available online 5 December 2017

\section{Keywords:}

Bioconjugation

Glaser-Hay reaction

Alkyne

Unnatural amino acid

\begin{abstract}
A B S T R A C T
The efficient preparation of protein bioconjugates represents a route to novel materials, diagnostics, and therapeutics. We previously reported a novel bioorthogonal Glaser-Hay reaction for the preparation of covalent linkages between proteins and a reaction partner; however, deleterious protein degradation was observed under extended reaction conditions. Herein, we describe the systematic optimization of the reaction to increase coupling efficiency and decrease protein degradation. Two optimized conditions were identified varying either the $\mathrm{pH}$ of the reaction or the bidentate ligand employed, allowing for more rapid conjugations and/or less protein oxidation.
\end{abstract}

(c) 2017 Elsevier Inc. All rights reserved.

\section{Introduction}

With widespread applications in the fields of medicine, materials, and pharmaceuticals, bioconjugate chemistry is a rapidly growing area of chemical research. Bioconjugates are comprised of a biological macromolecule linked to a second molecule, often a surface, probe, nanoparticle, or another biomolecule [1,2]. Protein bioconjugates, wherein at least one of the conjugate partners is a protein, have been utilized to enhance drug delivery and cellular imaging through the use of antibodies conjugated to cytotoxic drug molecules and luminescent quantum dots, in addition to numerous other applications [3-9].

The preparation of covalently-linked protein bioconjugates is often accomplished through reaction of a protein's native nucleophilic residues, such as lysine, cysteine, and serine [10]. However, through this method, bioconjugation can occur at multiple residues within the protein, resulting in non-specific conjugation at a varying number of positions $[10,11]$. To overcome this lack of selectivity, unnatural amino acids (UAAs) can be site-specifically introduced into proteins via suppression of the amber stop codon (TAG) by an evolved orthogonal amino acyl synthetase (aaRS)/ tRNA pair [12-14]. The incorporation of a UAA bearing a chemical moiety not found within the twenty naturally occurring amino acids not only provides a specific site for conjugation of the protein, but also allows access to several useful conjugation methods previously unavailable for bioconjugation reactions involving proteins $[15,16]$.

\footnotetext{
* Corresponding author.

E-mail address: dyoung01@wm.edu (D.D. Young).
}

The Glaser-Hay coupling of two terminal alkynes is among these now-accessible protein bioconjugation reactions due to the preparation of a terminal alkyne containing UAA, p-propargyloxyphenylalanine $(p \operatorname{PrF}, \mathbf{1})$ [17]. This coupling reaction affords a well-defined, linear 1,3-diyne via a copper (I) catalyst and bidentate nitrogenous ligand (Fig. 1), most often $\mathrm{N}, \mathrm{N}, \mathrm{N}^{\prime}, \mathrm{N}^{\prime}$-tetramethyle thylenediamine (TMEDA, 2) [18-21]. Moreover, this generates a new carbon-carbon bond that is highly stable and unreactive under typical physiological conditions [18]. Diynes and other conjugated acetylenic structures generated from the Glaser-Hay coupling reaction have many useful applications. Such diynes are the starting point for many cycloaddition reactions yielding carbo- and heterocycles that display interesting biological, optoelectronic, and photochemical properties [22-26]. Additionally, the Glaser-Hay reaction can be utilized to generate diacetylenes employed in crystal-forming polymerization reactions [27], or to prepare classes of macrocyclic compounds with diverse applications in supramolecular chemistry and nanotechnology [28,29].

\section{Materials and methods}

\subsection{Expression of GFP containing $p P r F$}

A pET-GFP-TAG plasmid $(0.5 \mu \mathrm{L})$ was co-transformed with a pEVOL-pPrF aaRS plasmid $(0.5 \mu \mathrm{L})$ into Escherichia coli BL21 (DE3) competent cells using an Eppendorf Eporator electroporator. The cells were then plated $(100 \mu \mathrm{L})$ on LB agar supplemented with ampicillin $(50 \mu \mathrm{g} / \mathrm{mL})$ and chloramphenicol $(34 \mu \mathrm{g} / \mathrm{mL})$, then incubated $16 \mathrm{~h}$ at $37^{\circ} \mathrm{C}$. One colony was used to inoculate LB media $(10 \mathrm{~mL})$ containing ampicillin and chloramphenicol. The culture 


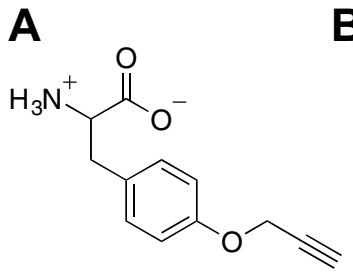

1

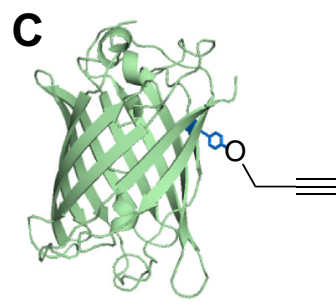

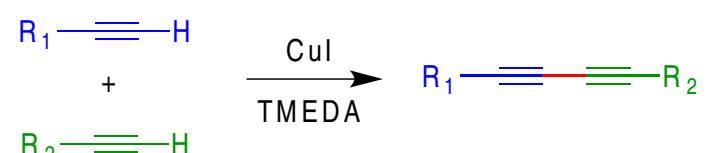

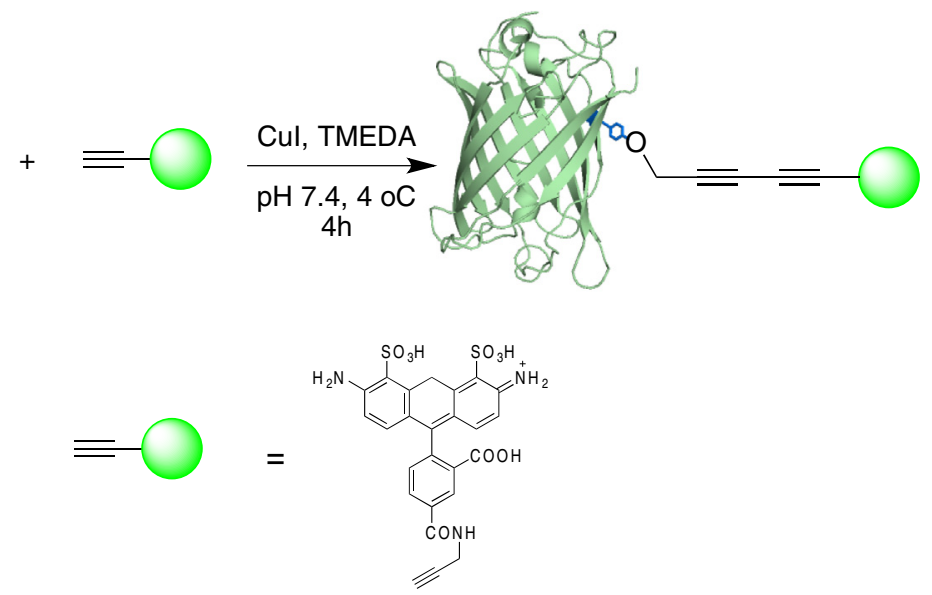

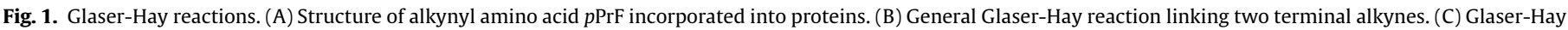
bioconjugation of a protein.

was incubated overnight at $37^{\circ} \mathrm{C}$ and used to initiate an expression culture (250 mL media, ampicillin $50 \mu \mathrm{g} / \mathrm{mL}$, chloramphenicol 34 $\mu \mathrm{g} / \mathrm{mL}$ ) at an $\mathrm{OD} 600=0.1$. The cultures were incubated at $37^{\circ} \mathrm{C}$ to an OD600 $=0.6$. Protein expression was induced by addition of $20 \%$ arabinose $(250 \mu \mathrm{L}), 0.8 \mathrm{mM}$ isopropyl- $\beta$-D-1-thiogalactopyra noside (IPTG; $250 \mu \mathrm{L}$ ), and $p \operatorname{PrF}(\mathbf{1})(2.5 \mathrm{~mL}, 100 \mathrm{mM})$. Cultures were incubated at $30^{\circ} \mathrm{C}$ overnight, then pelleted by centrifugation $(5000 \mathrm{rpm}, 10 \mathrm{~min})$. Pelleted cells were stored at $-80^{\circ} \mathrm{C}$ until purification. The cell pellet was resuspended with $500 \mu \mathrm{L}$ of Bugbuster (Novagen), and $200 \mu \mathrm{L}$ of lysis buffer and incubated for 20 mins at $37^{\circ} \mathrm{C}$. Cellular debris was pelleted out by centrifugation at $5000 \mathrm{rpm}$ for $10 \mathrm{mins}$ and the supernatant was added to an equilibrated Ni-NTA resin $(200 \mu \mathrm{L})$. GFP was purified according to manufacturer's protocol before being analyzed by SDS-PAGE (BioRad 10\% precast gels, $150 \mathrm{~V}, 1.5 \mathrm{~h}$ ). Gels were stained using Coomassie Brilliant Blue, and destained using destain solution (60\% deionized $\mathrm{H}_{2} \mathrm{O}, 30 \% \mathrm{MeOH}, 10 \%$ acetic acid).

\subsection{Biological Glaser-Hay reaction under optimized condition 1}

To a sterile $1.5 \mathrm{~mL}$ eppendorf tube, the following were added: 5 $\mu \mathrm{L}$ of a vigorously shaken solution of $\mathrm{CuI}\left(500 \mathrm{mM}\right.$ in $\left.\mathrm{H}_{2} \mathrm{O}\right)$ and $5 \mu \mathrm{L}$ of tetramethylethylenediamine ( 2 in $500 \mathrm{mM}$ in $\mathrm{H}_{2} \mathrm{O}$ ). The two solutions were thoroughly mixed by pipetting. Next, $30 \mu \mathrm{L}$ of GFP containing a terminal alkyne UAA (GFP/pPrF; $\mathrm{pH}=6.0,1.04 \pm 0.0$ $3 \mathrm{mg} / \mathrm{mL}$ ) and $20 \mu \mathrm{L}$ of AlexaFluor-488 Alkyne (1 mM in DMSO) were added to the tube. The reaction was incubated at room temperature $\left(22^{\circ} \mathrm{C}\right)$. After $4 \mathrm{~h}$, excess reactants were removed by buffer exchange using Spin-X UF concentrator columns. The reaction was washed with PBS $(8 \times 200 \mu \mathrm{L})$ to a final volume of $50 \mu \mathrm{L}$. The reaction was analyzed by SDS-PAGE and imaged immediately to analyze fluorescence. The gel was then stained for $3 \mathrm{~h}$ using Coomassie Brilliant Blue, then destained overnight using a methanol solution (60\% deionized $\mathrm{H} 2 \mathrm{O}, 30 \% \mathrm{MeOH}, 10 \%$ acetic acid). The gel was then analyzed again on the gel imager.

\subsection{Biological Glaser-Hay reaction under optimized condition 2}

To a sterile $1.5 \mathrm{~mL}$ eppendorf tube, the following were added: 5 $\mu \mathrm{L}$ of a vigorously shaken solution of $\mathrm{CuI}\left(500 \mathrm{mM}\right.$ in $\left.\mathrm{H}_{2} \mathrm{O}\right)$ and $5 \mu \mathrm{L}$ of 2,2'-Bipyridine-4,4'-dicarboxylic acid $(\mathbf{1 0}, 500 \mathrm{mM}$ in $1 \mathrm{M}$ $\mathrm{NaOH}$ ). The two solutions were thoroughly mixed by pipetting until a dark brown color was achieved. Next, $30 \mu \mathrm{L}$ of GFP containing a terminal alkyne UAA (GFP/pPrF; $\mathrm{pH}=8.0,1.04 \pm 0.03 \mathrm{mg} / \mathrm{mL}$ ) and $20 \mu \mathrm{L}$ of AlexaFluor-488 Alkyne ( $1 \mathrm{mM}$ in DMSO) were added to the tube. The reaction was incubated at room temperature $\left(22^{\circ} \mathrm{C}\right)$. After $8 \mathrm{~h}$, excess reactants were removed by buffer exchange using Spin-X UF concentrator columns. The reaction was washed with PBS $(8 \times 200 \mu \mathrm{L})$ to a final volume of $50 \mu \mathrm{L}$. The reaction was analyzed by SDS-PAGE and imaged immediately to analyze fluorescence. The gel was then stained for $3 \mathrm{~h}$ using Coomassie Brilliant Blue, then destained overnight using a methanol solution (60\% deionized $\mathrm{H} 2 \mathrm{O}, 30 \% \mathrm{MeOH}, 10 \%$ acetic acid). The gel was then analyzed again on the gel imager.

\section{Results and discussion}

Transferring the Glaser-Hay coupling to a biological setting for use in bioconjugations necessitates relatively mild reaction conditions that are compatible with physiological systems, namely a moderate temperature, aqueous environment, and short reaction time. Several past experiments have successfully employed the Glaser-Hay reaction on biologically relevant molecules, though not necessarily under mild conditions. In 2015, oxidative coupling of terminal alkynes was reported with the formation of peptoid dimers at $90^{\circ} \mathrm{C}$ in DMSO, and again with macrocyclization of tetrapeptides at $60^{\circ} \mathrm{C}$ using $\mathrm{Cu}\left(\mathrm{OAc}_{2}\right)$ and $\mathrm{NiCl}_{2}$ catalysts [30,31].

Our previous work demonstrated the first successful biological Glaser-Hay coupling in a full-length protein and under mild reaction conditions (Fig. 1C) [32-34]. With incorporation of $p \operatorname{PrF}$ into green fluorescent protein (GFP), we generated a protein- 
fluorophore bioconjugate at $4{ }^{\circ} \mathrm{C}$ after $4 \mathrm{~h}$. Despite having successfully employed the Glaser-Hay coupling in a biological context, we observed noticeable protein degradation after about $6 \mathrm{~h}$. We proposed that this degradation was potentially due to hydroxyl radicals generated from the copper (II)-hydroxyl intermediate in the catalytic cycle of the Glaser-Hay reaction, which is known to be deleterious to living systems $[19,35]$. This protein oxidation was characterized by MS analysis, ultimately resulting in loss of protein product (See Supporting Information). To avoid protein degradation, we became interested in developing means to circumvent the production of harmful radical species while generating the same internal 1,3-diyne structure. One such method that we developed implemented the Cadiot-Chodkiewicz coupling of a terminal alkyne and halo-alkyne to afford a protein-fluorophore bioconjugate [36]. Because the Cadiot-Chodkiewicz mechanism is thought to cycle between the copper (I) and copper (III) states while avoiding the harmful copper (II) state, reaction times could be extended with minimal protein degradation [37]. Furthermore, under the Cadiot-Chodkiewicz mechanism, we were able to reduce the amount of catalytic copper ten-fold from that required by the Glaser-Hay mechanism and achieve satisfactory coupling. While the Cadiot-Chodkiewicz coupling occurred with less protein degradation, it did require additional synthetic steps to access bromoalkyne amino acids or brominated coupling partners. Because the terminal alkyne amino acid is commercially available, and an orthogonal aaRS/tRNA pair has specifically been evolved to incorporate it, the Glaser-Hay coupling is more easily accessible. Thus, we aim to systematically optimize the traditional Glaser-Hay reaction to increase coupling efficiency and preserve protein from degradation, allowing it to find more widespread utility.

In order to further optimize the biological Glaser-Hay reaction, a $250 \mathrm{~mL}$ expression of GFP harbouring $p \mathrm{PrF}$ in position 151 was performed to ensure that all reactions were conducted on the same protein batch $(1.0 \mathrm{mg} / \mathrm{mL})$ to remove variability between expressions. With the $p$ PrF-GFP in hand, a range of experimental variables was examined in a systematic fashion when reacting the mutant GFP with an AlexaFluor-488 alkyne dye. Due to the production of biologically deleterious $\mathrm{Cu}(\mathrm{II})$ in the catalytic cycle, we examined the addition of both reducing agents and radical scavengers to the reaction as a mechanism to mitigate the potential damage caused by the radicals initiated by the $\mathrm{Cu}(\mathrm{II})$ species. Additionally, we examined the effects of a wide variety of copper sources and ligands to further activate the copper center, as well as buffers at varying $\mathrm{pH}$. Each variable was independently varied based on the previously reported conditions, and optimized conditions were then screened in combination to elucidate the best Glaser-Hay bioconjugation conditions.

Initial studies examined the addition of reducing agents to the reaction to reduce harmful $\mathrm{Cu}(\mathrm{II})$ back to the $\mathrm{Cu}(\mathrm{I})$ species. Based on their biological compatibility, $\beta$-mercaptoethanol, tris(2carboxyethyl)phosphine (TCEP), dithiothreitol (DTT) and nicotinamide adenine dinucleotide (NADH) were selected for analysis. Glaser-Hay reactions were conducted with the $p$ PrF-GFP and AlexaFluor-488 alkyne in the presence of a reducing agent (500 $\mathrm{mM}$ ), TMEDA and CuI for $4 \mathrm{~h}$ at $4{ }^{\circ} \mathrm{C}$. Control reactions were also performed in the absence of reducing agent, or in the absence of the CuI/TMEDA. After purification and buffer exchange, the reactions were analyzed by SDS-PAGE for protein degradation and coupling efficiency. Fluorescence intensity indicated the effective coupling reaction as the GFP is denatured and no longer fluorescent, while the coupling to the fluorophore re-establishes a fluorescent signal. Coomassie staining was also performed to indicate protein presence and relative degradation. Unfortunately, no reducing agent afforded better coupling conditions than the original conditions, and DTT dramatically inhibited efficient coupling (see Supporting Information, Fig. 1). Similar results were observed when radical scavengers were employed including cysteine, oleic acid, and ascorbic acid. Ascorbic acid also hindered the GlaserHay reaction from occurring and increased the level of protein degradation (see Supporting Information, Fig. 1).

Based on the literature, a variety of copper sources have been utilized in the Glaser-Hay reaction, and we next investigated if any were more advantageous than the previously reported copper iodide. Reactions were performed using copper(I) iodide, copper(I) chloride, copper(II) chloride, and copper(II) sulfate. Reactions were additionally performed using copper(II) chloride with nicotinamide adenine dinucleotide and copper(II) sulfate with nicotinamide adenine dinucleotide to test whether a copper(II) catalyst reduced to copper(I) would be advantageous for the reaction. None of these copper sources were able to outperform the previously established CuI, as determined by SDS-PAGE (see Supporting Information, Fig. 3).

We next investigated the effect of the ligand on the Glaser-Hay bioconjugation. Early attempts with nitrogenous monodentate ligands (TEA, pyrrolidine, etc.) did not lead to substantial coupling, and a more thorough investigation of bidentate nitrogenous ligands followed (see Fig. 2). Ligands $\mathbf{3}$ and $\mathbf{4}$ were selected to investigate the optimal chelation ring size, and $\mathbf{5}, \mathbf{6}$, and $\mathbf{7}$ were employed to probe the substitution of the nitrogen atom. Finally, $\mathbf{8}$ and $\mathbf{9}$ were selected to alter the electronic environment of the nitrogen atoms, while simultaneously testing the necessity of chelation. These experiments indicated that both the 2,2bipyridyl ligand (8) and the diaminopropane ligand (3), to a much lesser extent, were as good as or better than $\mathbf{2}$, with 4 -fold and $0.8-$ 1.2-fold increases in coupling efficiency, respectively. However, 8 had limited solubility in aqueous media, so the commercially available $\mathbf{1 0}$ was explored to overcome these issues. Gratifyingly, $\mathbf{1 0}$ afforded a coupling effiency nearly 7 times greater than that of $\mathbf{2}$. We hypothesize that the combination of the electronic effects of the bipyridyl ligand coupled with the rigidity of the ligand aided in the chelation and activation of the copper center to improve the reaction.

After elucidating that ligand $\mathbf{1 0}$ resulted in superior coupling, we explored whether other copper sources, radical scavengers, or reducing agents would further increase the coupling efficiency with these ligands. Varying these other conditions did not afford enhanced results, as copper(I) iodide with no added agents remained the best condition using either $\mathbf{2}$ or $\mathbf{1 0}$.

The next variable examined was the effect of solution $\mathrm{pH}$ on the reaction. GFP was buffer exchanged into $\mathrm{PBS}$ at $\mathrm{pH} 6.0, \mathrm{pH} 7.0, \mathrm{pH}$ 8.0, and $\mathrm{pH}$ 9.0. Both the original ligand (2) and $\mathbf{1 0}$ were used for Glaser-Hay couplings in each pH solution. Interestingly, reactions employing 2 exhibited higher coupling ratios at $\mathrm{pH} 6.0$, and reactions with $\mathbf{1 0}$ had the highest Glaser-Hay coupling at pH 8.0.

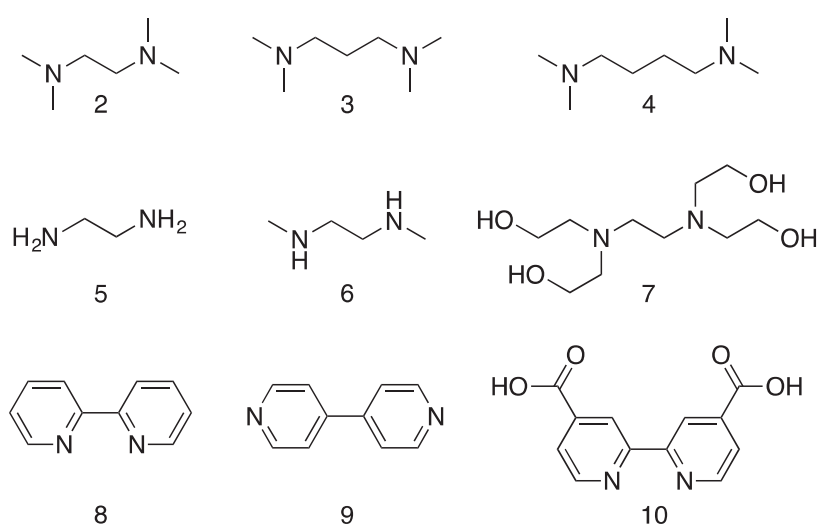

Fig. 2. Structures of ligands employed in Glaser-Hay bioconjugation optimization. 

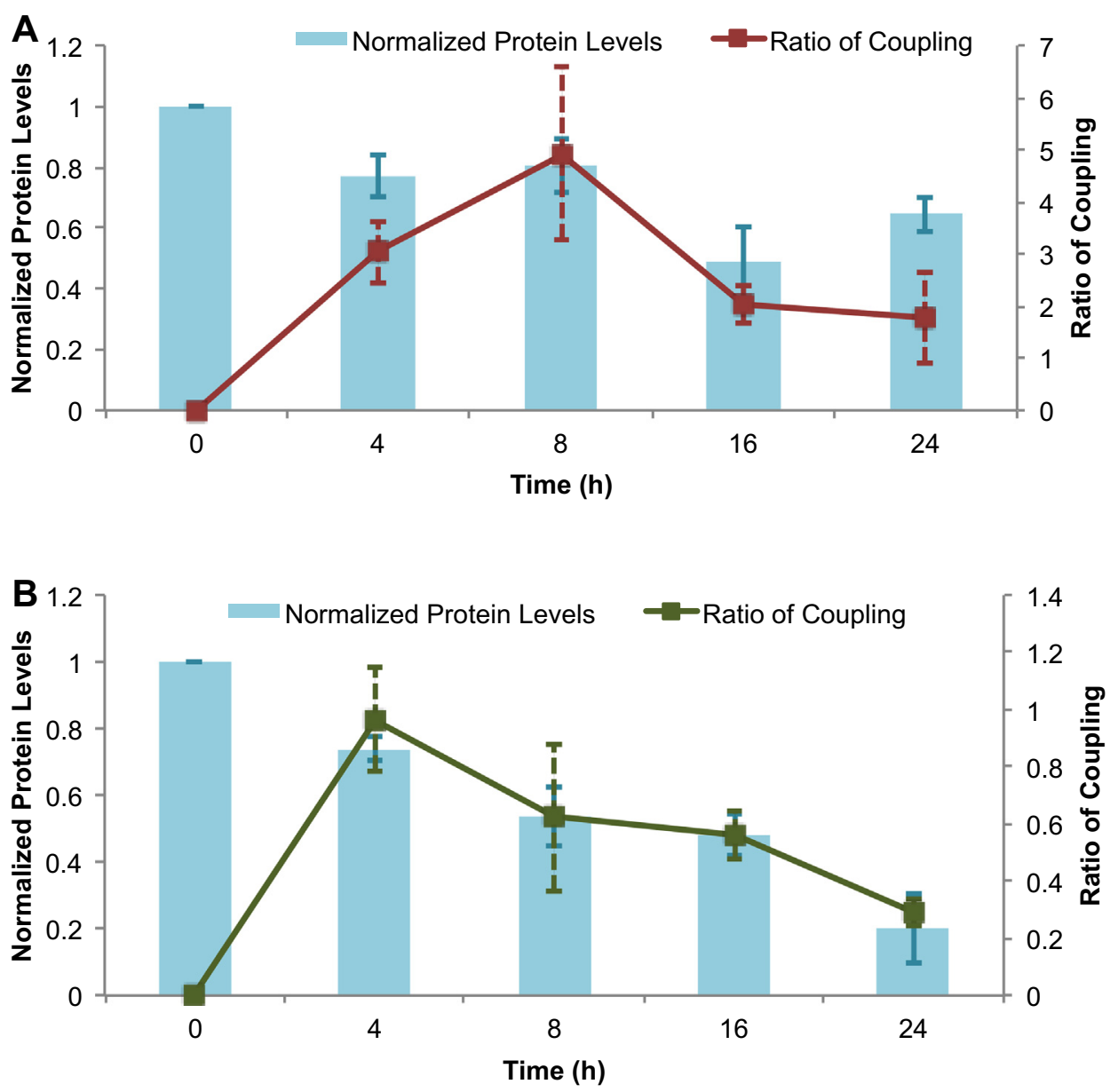

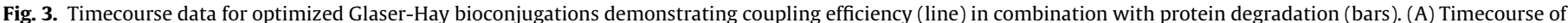

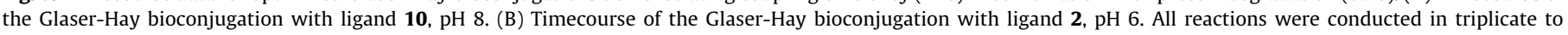
establish appropriate standard deviations.

A

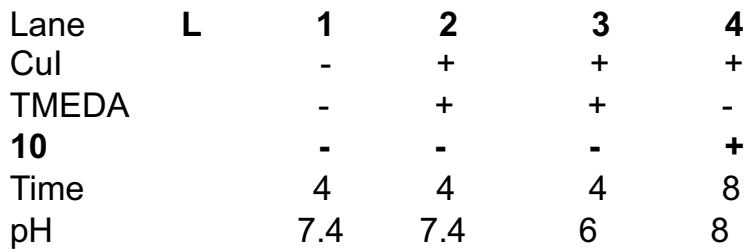
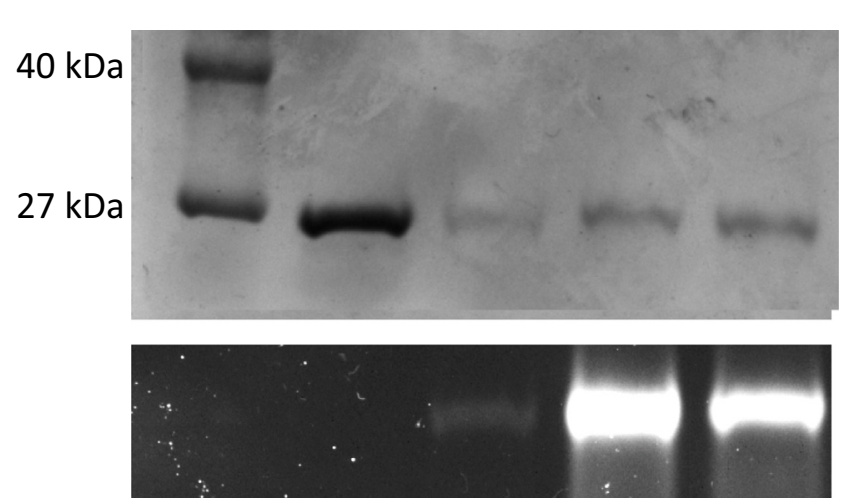

B

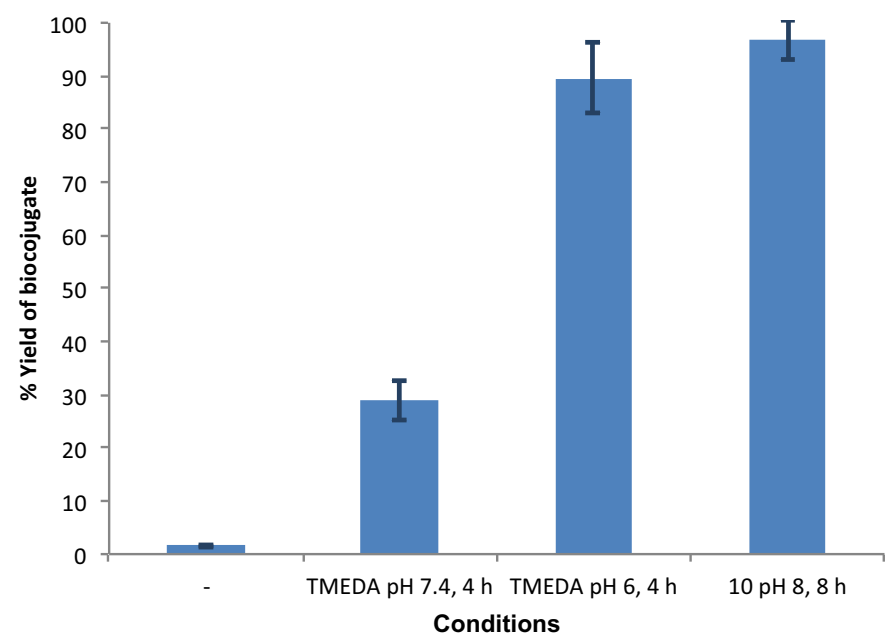

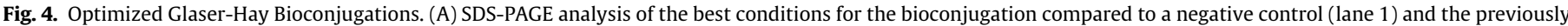

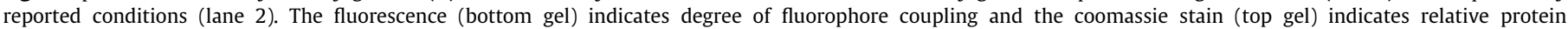

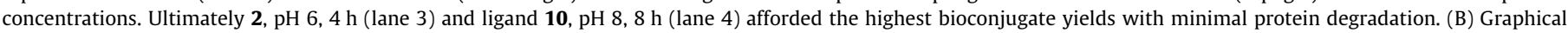
representation of the gel densiometry analysis performed on three independent SDS-PAGE experiments quantifying the optimized conditions. 
Additionally, less degradation of protein was observed under both of these new conditions, as observed by comparable amounts of protein on the gels as the control reactions, and minimized oxidative damage by MS. Due to the decreased oxidative damage, we then employed these conditions at different temperatures to see if coupling ratios could be increased further, as the previously published conditions were performed at $4{ }^{\circ} \mathrm{C}$ to minimize degradation. Identical reactions with both ligands were conducted at 4, 22, 30, and $37^{\circ} \mathrm{C}$ for $4 \mathrm{~h}$. After quantitation by SDS-PAGE, the most effective coupling condition with the least amount of protein degradation was found to be room temperature $\left(22^{\circ} \mathrm{C}\right)$ for both ligands. As a final optimization, the two ligands were employed at their appropriate $\mathrm{pH}$ and at room temperature over a timespan of $24 \mathrm{~h}$ (Fig. 3). The results indicate that for both conditions, protein degradation begins to become a factor after approximately $8 \mathrm{~h}$, leading to a subsequent decrease in Glaser-Hay bioconjugations. The timecourse experiments also reveal that the conjugations employing $\mathbf{1 0}$ result in less overall protein degradation relative to both conditions using 2. This decreased degradation allows for increased reaction times, that facilitate higher levels of coupling. In the case of $\mathbf{2}$, lowering the $\mathrm{pH}$ to 6.0 appears to accelerate the reaction rate, improving coupling prior to degradation.

Ultimately, we elucidated two optimized conditions that improved coupling efficiency and/or minimized protein degradation, resulting in yields of $\sim 95 \%$ or greater as determined by absorbance spectroscopy. For ligand 2, reactions performed at $22{ }^{\circ} \mathrm{C}, \mathrm{pH}$ 6.0 , for $4 \mathrm{~h}$ afforded the best results, while $\mathbf{1 0}$ functioned best at 22 ${ }^{\circ} \mathrm{C}, \mathrm{pH} \mathrm{8.0,}$, for $8 \mathrm{~h}$ (Fig. 4). Each of these conditions facilitates substantial improvement over the previously published conditions of $2,4^{\circ} \mathrm{C}, \mathrm{pH} 7.4$, for $4 \mathrm{~h}$. Selection of appropriate ligand is most likely application dependent, as $\mathbf{2}$ affords shorter reaction times to obtain the bioconjugate, while $\mathbf{1 0}$ provides slower couplings, but with less protein degradation.

\section{Conclusion}

In conclusion, two new reaction conditions have been developed towards optimizing Glaser-Hay bioconjugations. The ability to increase coupling efficiency, while simultaneously decrease harmful protein degradation, increases the overall utility of this reaction. Expanding the chemical toolbox of bioorthogonal bioconjugations is essential towards the preparation of various conjugates having medical and materials based applications. The Glaser-Hay reaction in particular is unique in its installation of a linear, carbon-carbon covalent bond, which also facilitates secondary reactions from the diyne moiety. Either lowering the $\mathrm{pH}$ with the traditional TMEDA ligand, or employing a carboxylated biphenyl ligand generates more efficient couplings with less degradation than the previously reported conditions.

\section{Acknowledgements}

This research was funded by the National Institute of General Medical Sciences of the NIH (R15GM113203), The Camille and Henry Dreyfus Foundation (TH-17-020) and the Arnold and Mabel Beckman Foundation. We would also like to thank Peter Schultz for providing the pEVOL plasmids employed in the study.

\section{Appendix A. Supplementary material}

Supplementary data associated with this article can be found, in the online version, at https://doi.org/10.1016/j.bioorg.2017.11.020.

\section{References}

[1] G.T. Hermanson, Bioconjugate Techniques, tird ed., Academic Press, London, UK, 1996.

[2] K. Lang, J. Chin, Cellular incorporation of unnatural amino acids and bioorthogonal labeling of proteins, Chem. Rev. 114 (9) (2014) 47644806.

[3] E.L. Sievers, P.D. Senter, Antibody-drug conjugates in cancer therapy, Annu. Rev. Med. 64 (2013) 15-29.

[4] J.K. Jaiswal, H. Mattoussi, J.M. Mauro, S.M. Simon, Long-term multiple color imaging of live cells using quantum dot bioconjugates, Nat. Biotechnol. 21 (1) (2003) 47-51.

[5] X. Gao, Y. Cui, R.M. Levenson, L.W. Chung, S. Nie, In vivo cancer targeting and imaging with semiconductor quantum dots, Nat. Biotechnol. 22 (8) (2004) 969-976.

[6] S. Ghosh, P. Kao, A. Mccue, H. Chappelle, Use of maleimide-thiol coupling chemistry for efficient syntheses of oligonucleotide-enzyme conjugate hybridization probes, Bioconjug Chem. 1 (1) (1990) 71-76.

[7] P. Kumaresan, J. Luo, A. Song, J. Marik, K. Lam, Evaluation of ketone-oxime method for developing therapeutic on-demand cleavable immunoconjugates, Bioconjug. Chem. 19 (6) (2008) 1313-1318.

[8] P. Khare, A. Jain, A. Gulbake, V. Soni, N. Jain, S. Jain, Bioconjugates: harnessing potential for effective therapeutics, Crit. Rev. Therap. Drug Carr. Sys. 26 (2) (2009) 119-155.

[9] J. Kalia, R. Raines, Advances in bioconjugation, Curr. Org. Chem. 14 (2) (2010) 138-147.

[10] N. Stephanopoulos, M. Francis, Choosing an effective protein bioconjugation strategy, Nat. Chem. Biol. 7 (12) (2011) 876-884.

[11] M.T. Smith, J.C. Wu, C.T. Varner, B.C. Bundy, Enhanced protein stability through minimally invasive, direct, covalent, and site-specific immobilization, Biotechnol. Prog. 29 (1) (2013) 247-254.

[12] C. Liu, P. Schultz, R. Kornberg, C. Raetz, J. Rothman, J. Thorner, Adding new chemistries to the genetic code, Ann. Rev. Biochem. 79 (79) (2010) 413-444.

[13] L. Wang, P.G. Schultz, Expanding the genetic code, Angew. Chem. Int. Ed. Engl. 44 (1) (2004) 34-66.

[14] T.S. Young, P.G. Schultz, Beyond the canonical 20 amino acids: expanding the genetic lexicon, J. Biol. Chem. 285 (15) (2010) 11039-11044.

[15] C.H. Kim, J.Y. Axup, P.G. Schultz, Protein conjugation with genetically encoded unnatural amino acids, Curr. Opin. Chem. Biol. 17 (3) (2013) $412-419$.

[16] J. Maza, T. Jacobs, D. Uthappa, D. Young, Employing unnatural amino acids in the preparation of bioconjugates, Synlett 27 (6) (2016) 885.

[17] A. Deiters, P.G. Schultz, In vivo incorporation of an alkyne into proteins in Escherichia coli, Bioorg. Med. Chem. Lett. 15 (5) (2005) 1521-1524.

[18] M. Vilhelmsen, J. Jensen, C. Tortzen, M. Nielsen, The Glaser-Hay reaction: optimization and scope based on C-13 NMR kinetics experiments, Eur. J. Org. Chem. 4 (2013) 701-711.

[19] L. Fomina, B. Vazquez, E. Tkatchouk, S. Fomine, The Glaser reaction mechanism A DFT study, Tetrahedron 58 (33) (2002) 6741-6747.

[20] A. Hay, Oxidative coupling of acetylenes, J. Org. Chem. 27 (9) (1962) 3320.

[21] C. Glaser, Ber. Dtsch. Chem. Ges. 2 (1896) 422-424.

[22] T. Nizami, R. Hua, Cycloaddition of 1,3-butadiynes: efficient synthesis of carbo- and heterocycles, Molecules 19 (9) (2014) 13788-13802.

[23] L. Yang, R. Hua, Cycloaddition of 1,4-Diaryl-1,3-butadiynes with nitriles: an atom-economic one-pot approach to benzo[f]quinazolines, Chem. Lett. 42 (7) (2013) 769-771.

[24] H. Sun, X. Wu, R. Hua, Copper(I)-catalyzed reaction of diaryl buta-1,3-diynes with cyclic amines: an atom-economic approach to amino-substituted naphthalene derivatives, Tet. Lett. 52 (34) (2011) 4408-4411.

[25] B. Pigulski, P. Mecik, J. Cichos, S. Szafert, Use of stable amine-capped polyynes in the regioselective synthesis of push-pull thiophenes, J. Org. Chem. 82 (3) (2017) 1487-1498.

[26] D. Yu, F. de Azambuja, T. Gensch, C. Daniliuc, F. Glorius, The C-H activation/1,3diyne strategy: highly selective direct synthesis of diverse bisheterocycles by Rh-III catalysis, Angew. Chem. Int. Ed. 53 (36) (2014) 9650-9654.

[27] H. Matsuda, H. Nakanishi, T. Hosomi, M. Kato, Synthesis and solid-state polymerization of a new diacetylene, Macromolecules 21 (5) (1988) 12381240.

[28] M. Iyoda, J. Yamakawa, M. Rahman, Conjugated macrocycles: concepts and applications, Angew. Chem. Int. Ed. 50 (45) (2011) 10522-10553.

[29] K. Sindhu, G. Anilkumar, Recent advances and applications of Glaser coupling employing greener protocols, RSC Adv. 4 (53) (2014) 27867-27887.

[30] M. Brauer, R. Neves, B. Westermann, R. Heinke, L. Wessjohann, Synthesis of antibacterial 1,3-diyne-linked peptoids from an Ugi-4CR/Glaser coupling approach, Beil. J. Org. Chem. 11 (2015) 1-6.

[31] S. Verlinden, N. Geudens, J. Martins, D. Tourwe, S. Ballet, G. Verniest, Oxidative alpha, omega-diyne coupling as an approach towards novel peptidic macrocycles, Org. Biomol. Chem. 13 (36) (2015) 9398-9404.

[32] J.S. Lampkowski, J.K. Villa, T.S. Young, D.D. Young, Development and optimization of Glaser-Hay bioconjugations, Angew. Chem. Int. Ed. Engl. 54 (2015) 9343-9346.

[33] J.C. Maza, J.R. McKenna, B.K. Raliski, M.T. Freedman, D.D. Young, Synthesis and incorporation of unnatural amino acids to probe and optimize protein bioconjugations, Bioconjug. Chem. 26 (2015) 1884-1889. 
[34] J. Maza, C. Howard, M. Vipani, C. Travis, D. Young, Utilization of alkyne bioconjugations to modulate protein function, Bioorg. Med. Chem. Lett. 27 (1) (2017) 30-33.

[35] J. Ueda, Y. Shimazu, T. Ozawa, Reactions of copper(II)-oligopeptide complexes with hydrogen peroxide: effects of biological reductants, Free Radic. Biol. Med. 18 (5) (1995) 929-933.
[36] J. Maza, Z. Nimmo, D. Young, Expanding the scope of alkyne-mediated bioconjugations utilizing unnatural amino acids, Chem. Commun. 52 (1) (2016) 88-91.

[37] J. Philippe, W. Chodkiewiz, P. Cadiot, Coupling of 1-haloalkynes with true acetylenes-utilization of 1-chloroalkynes, Tet. Lett. 1970 (21) (1970) 1975. 